Article

\title{
The Impacts of COVID-19 Crisis over the Tourism Expectations of the Azores Archipelago Residents
}

\author{
Gualter Couto ${ }^{1, * \mathbb{C}}$, Rui Alexandre Castanho ${ }^{1,2,3,4, * \mathbb{C}}$, Pedro Pimentel ${ }^{1}\left(\mathbb{D}\right.$, Célia Carvalho ${ }^{5,6}(\mathbb{D}$, \\ Áurea Sousa ${ }^{7}$ (i) and Carlos Santos ${ }^{1}$ \\ 1 School of Business and Economics, University of Azores and CEEAplA, 9500-321 Ponta Delgada, Portugal; \\ pedro.ms.pimentel@uac.pt (P.P.); carlos.as.santos@uac.pt (C.S.) \\ 2 Faculty of Applied Sciences, WSB University in Dąbrowa Górnicza, 41-300 Dąbrowa Górnicza, Poland \\ 3 VALORIZA-Research Centre for Endogenous Resource Valorization, 7300 Portalegre, Portugal \\ 4 CITUR-Madeira-Centre for Tourism Research, Development and Innovation, \\ 9000-082 Funchal-Madeira, Portugal \\ 5 Faculty of Social and Human Sciences, University of Azores and CINEICC - Cognitive and Behavioral \\ Centre for Research and Intervention, 9500-321 Ponta Delgada, Portugal; celia.mo.carvalho@uac.pt \\ 6 Faculty of Psychology and Educational Sciences, University of Coimbra, 3000-115 Coimbra, Portugal \\ 7 Faculty of Sciences and Technology, University of Azores and CEEAplA, 9500-321 Ponta Delgada, Portugal; \\ aurea.st.sousa@uac.pt \\ * Correspondence: gualter.mm.couto@uac.pt (G.C.); acastanho@wsb.edu.pl (R.A.C.)
}

Received: 13 August 2020; Accepted: 7 September 2020; Published: 15 September 2020

\begin{abstract}
Throughout history, times of crisis have always been preceded by periods of change. In fact, the current moment of health, economic, and social crisis that we are experiencing seems to be no exception. Tourism seems to be one of the most affected activities by the COVID-19 pandemic crisis-due not only the cancelled flights but also to the fear of being infected with the virus. In this sense, the present article intends to identify the Azores Archipelago residents' tourism expectations during the COVID-19 crisis. Using the Azores Islands as a case study and merging it with the authors' knowledge about this regional reality, it was possible to collect a substantial quantity of data. Thus, this study provides an in-depth perception of the main issues about how this pandemic crisis affects the tourism expectations of the Azores region residents, and consequently, how this situation will influence regional sustainable development. Through the study, it was possible to verify that the significant part of the Azores Archipelago residents (57.5\%) will not be going to travel to spend vacations in 2020. Additionally, $84.2 \%$ will have holidays in the region; therefore, they stay in the Azores Archipelago. Besides, this study shows that majority of the respondents (61.6\%) would not make a reservation for a 2020 vacation.
\end{abstract}

Keywords: Azores Islands; COVID-19; public perceptions; regional studies; socio-economy; sustainable tourism

\section{Introduction}

After it emerged in China, the novel coronavirus disease (COVID-19) has expanded into 196 of the 198 countries on the planet [1,2]. In fact, to accomplish this degree of contagion, the disease took only three months using human means of transport and communications. Consequently, until a few weeks ago, many countries were sure that it would not affect them, and now are fearful of a health catastrophe [1]. However, previous studies have shown the critical role of air travel in stimulating and expanding the propagation of infectious diseases such as COVID-19 [3-5].

Therefore, without a vaccine, the most efficient strategies to face the novel coronavirus, severe acute respiratory syndrome coronavirus type 2 (SARS-CoV-2), are social distancing and massive 
lockdowns. However, such confinement measures are not always an easy task to ask for. Such difficulties seem to be even more evident in economies very connected with the producing and selling of goods, and/or tourism - as is the example of many countries in Latin American or South American. In fact, Dominiq Abud [6], in a recent study regarding COVID-19 economic impacts on economy and tourism of Latin American countries, states that:

"If people do not have an income, do not demand products or services, then importation is not required, but what about production, when everything is limited to "Stay at home," and what is produced and mostly exported the region, are perishable products without markets currently or under a free zone regime, which do not reflect any kind of push in the trade balance in this part of the world."

For example, the Economic Commission for Latin America and the Caribbean, announces that the pandemic's economic implications may cause the region to lose at least $1.8 \%$ of GDP by 2020, given that expected decrease in the economic activity by the partners $[7,8]$. However, this economic deterioration is repeated, with higher or lower impacts, all over the world [9-11]. In this regard, tourism has not been an exception. In fact, it seems to be one of the most affected activities by this pandemic crisis-due to not only the cancelled flights but also the fear of being infected with the virus. Moreover, since the first half of 2020, most countries have implemented strict measures of social distance, as they imply that all non-essential activities are suspended. This measure has affected all sectors of society, but perhaps it has had the most significant impact on tourism because it has been discontinued entirely [12].

If we look at some of the past recent world crises of a similar typology-i.e., SARS (Severe Acute Respiratory Syndrome) in 2003, or the MERS (Middle East Respiratory Syndrome) in 2015; they also have considerable impacts in the tourism sector. However, on a much smaller scale than we are presented with by the COVID-19 outbreak [2]. In fact, according to the authors Gössling, Scott, and Hall (2020), it shows that: "( . . ) tourism as a system has been resilient to external shocks". Still, the COVID-19 crisis will have unprecedented impacts [10,13-15].

According to Burkle [16]: "The connections between pandemics and travel are fundamental to understanding health security and global change." In this regard, many authors have warned about the possibility of a pandemic crisis affecting society and tourism on a large scale (see: [17-26]). Even if tourism literature has increased considerably in recent decades, there are still many gaps; moreover, further research regarding the health crisis's impacts on tourism is one of these gaps.

Contextually, the present research aims to cover this gap, even if only in a specific region-the Azores Archipelago. Based on those issues, the following research question have been developed: "How has the Covid-19 Pandemic Crisis Affected the Azores Islands Residents' Tourism?"

In order to produce an answer to the study question, testing tools have been used regarding the tourism expectations of the Azores Archipelago residents based on the COVID-19 pandemic crisis.

Thus, the present research aims to determine and analyze the impacts of the COVID-19 pandemic crisis over the tourism expectations of Azores residents, by the assessment of their perceptions.

Besides, the study also expects to disclose directions for the main actors in the use of possible investment opportunities in regional tourism-i.e., as rural and slow tourism; thus, enabling a sustainable growth and development process in the archipelago.

\section{Material and Methods}

Recognizing the purpose of the study, different methods, including direct and secondary analysis methods and instruments, were used during the research. Therefore, the methodological approach was divided into four main phases closing with the impacts of the COVID-19 crisis over the tourism expectations of the Azores Archipelago residents (Figure 1).

Using the Azores region as a case study and merging it with the authors' knowledge about this regional reality, it was possible to collect a substantial quantity of data. Thus, getting an in-depth perception of the main issues about how this pandemic crisis affects the tourism expectations 
of the Azores Archipelago residents, and consequently, how this situation will influence regional sustainable development.

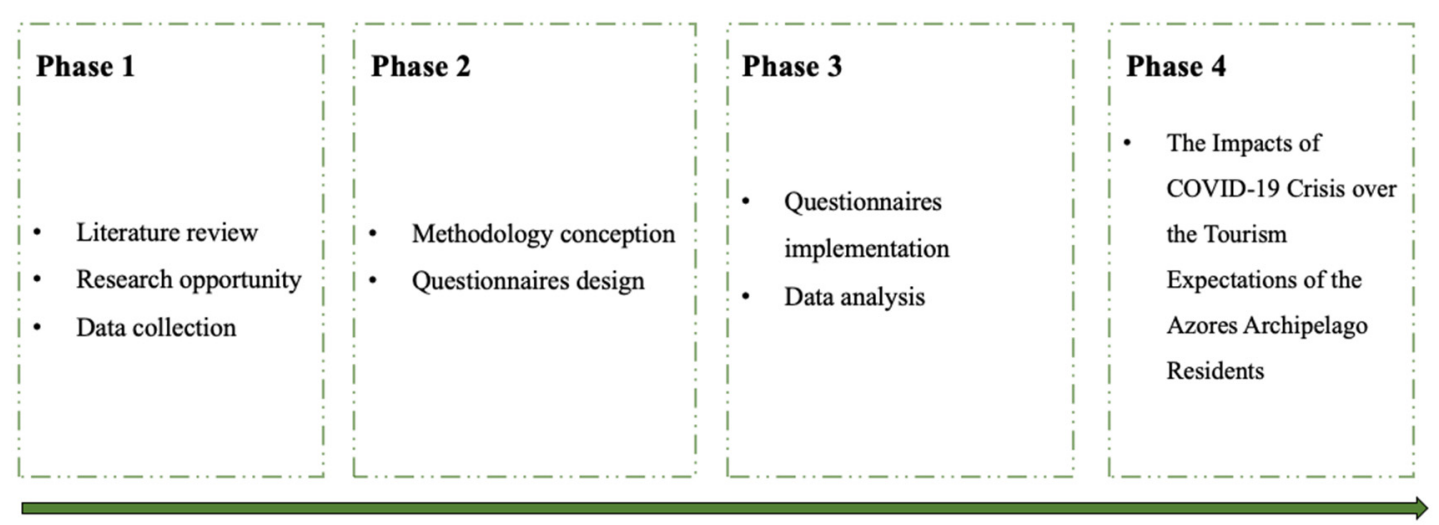

Figure 1. Methodological approach.

\subsection{Study Area: Azores Archipelago}

The Azores Archipelago is a Portuguese autonomous region and one of the outermost regions $(\mathrm{OR})$ of the European Union (EU). It contains nine islands positioned in the heart of the Atlantic Ocean, roughly halfway between Europe and the United States of America (Figure 2).

The archipelago has a strategic location, and it has been recognized as a sustainable nature-based destination [27]. Newly, due to its remoteness and astounding nature, it has been frequently distinguished by adventure tourism by international references like Bloomberg, Departures, BBC, Forbes, Geek Explorer, and Lonely Planet, among several others. Besides, the Azores natural and cultural heritage, along with the generalized rural environment, presents the Archipelago as the perfect place for slow adventures [28].

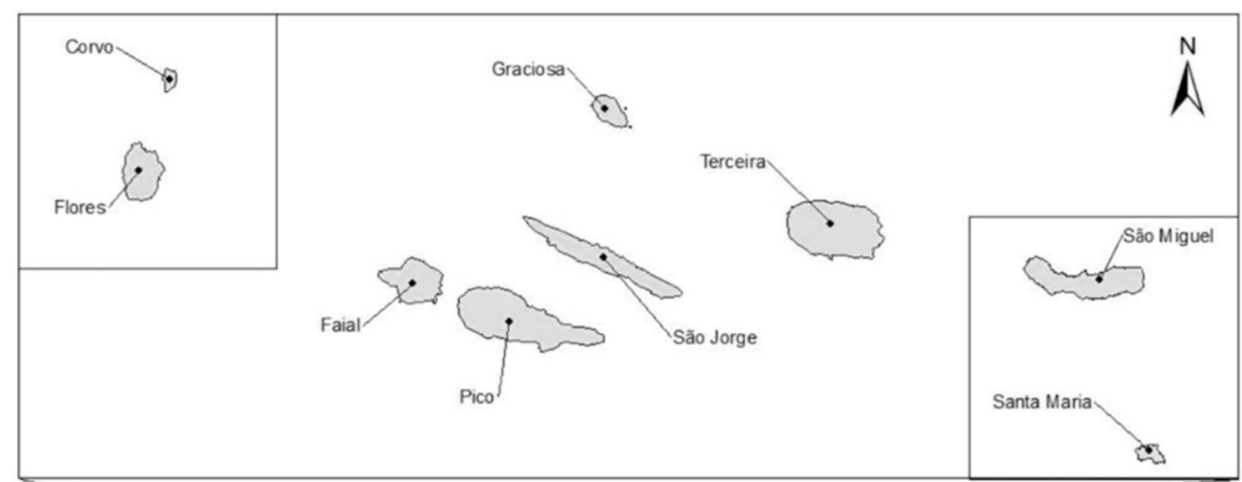

Figure 2. The Azores Archipelago ([29]).

The archipelago is strategically positioned as a sustainable nature-based destination. Vieira et al. [30] notice that each of the nine islands has its own identity. All islands share an extraordinary natural legacy but also have their unique landscape, traditions, cuisine, and architecture, which generate a vast touristic potential. Silva and Almeida [31] also observe that every island has the potential and strengths to develop active, nature, adventure, and sports tourism. These incredible natural resources and cultural identity provide the basis for unforgettable adventure tourism experiences in the region. Moreover, the partial liberalization of air transport in the Azores, which occurred in March 2015 and induced the start of low-cost airlines operations, has been increasing the number of tourists (especially first-time tourists) and favoring a significant change in the local market [32]. The local economy is changing, and increasing investment is being directed to tourism 
activities, ranging from accommodation to entertainment. Nonetheless, the Azores archipelago has natural constraints that demand constant attention. The heterogeneous territory's fragmentation resulted in nine very different islands in terms of area and natural resources, with significant land dispersion (some islands are very distant from the center of the archipelago, while others are very close to each other). For this reason, five islands-Santa Maria, Graciosa, São Jorge, Flores, and Corvo-have been identified as the "Cohesion Islands" (being the smallest islands or the ones with more significant challenges to their development) and benefit from positive discrimination in the regional economic policies. The remaining four islands—São Miguel, Terceira, Pico, and Faial—are the most developed, although substantial differences exist.

Tourism is perceived as a sector of high strategic importance for the Azores, which can contribute in a decisive way to the development and growth of the region [30]. Nature and adventure tourism are frontline products of this paradigm. Nevertheless, a lack of supply and players in these market segments has been recently identified, even though nature-based tourism products stand out as the ones with the highest potential [32]. As a consequence of the new tourism sector dynamics, more and more tourism activities companies and businesses were created, diversifying the supply of tourist experiences, especially activities connected to nature and adventure.

\subsection{Questionnaires Design and Implementation}

The questionnaire was designed considering web interviews. More specifically, we conducted an online survey using Google Forms. Although online surveys are susceptible to biases the results of an empirical study, such as in the case of the participants' age, this typology of interview was selected due to the need for social distancing in the actual pandemic crisis scenario.

The sample population consisted of the Azores region residents, which we believe are the most relevant participants for this research. The sample was composed of 704 individuals. The web interviews were carried out over the months of May and June of 2020.

Considering the purpose of the research, the authors selected short and direct questions regarding the COVID-19 situation and how it has affected their tourism intentions for 2020.

Once the data of the questionnaire tools have been collected, statistical analysis was first performed using the first spreadsheets to organize the gathered data and then refined by statistical analysis using SPSS.

\section{Results}

The results listed below are given by direct analysis by the performed questionnaires.

The questionnaire begins obtaining the sample profile of the participants (Table 1). Of the 704 participants in the study, $66.9 \%$ are female and $33.1 \%$ male. The participants were divided into three age groups: $18-34 ; 35-54$; and over 55 years. The most representative group was the 35-54-years-old group (53.9\%), followed by $18-34$ (24.0\%), with the least representative age group being the over 55 cohort $(22.1 \%)$. Regarding marital status, $64.2 \%$ of the participants are married or in a common-law situation; $10.3 \%$ were divorced, $23.4 \%$ single, and only $2.1 \%$ were widowed. The participants' most representative professional situation was that of superior staff $(31.7 \%)$ followed closely by intermediate staff $(30.8 \%)$, with the least representative situation being the unemployed $(4.1 \%)$. The academic degree most representative of the participants was University education (58.15), and the least representative was basic education (5.1\%). Concerning the respondents' island of residence, it was possible to identify that most are from the Azores Eastern Group (54.5\%), and the Azores Western Group shows the lowest number of participants (1.9\%), as shown in Table 1. In addition, the Gross Annual Household Income group with the higher percentage among the respondents was EUR 15,000 to $29,999(43.0 \%)$, and the lower value was found in the income group earning more than EUR $60,000(5.3 \%)$. 
Table 1. Sociodemographic aspects of the participants.

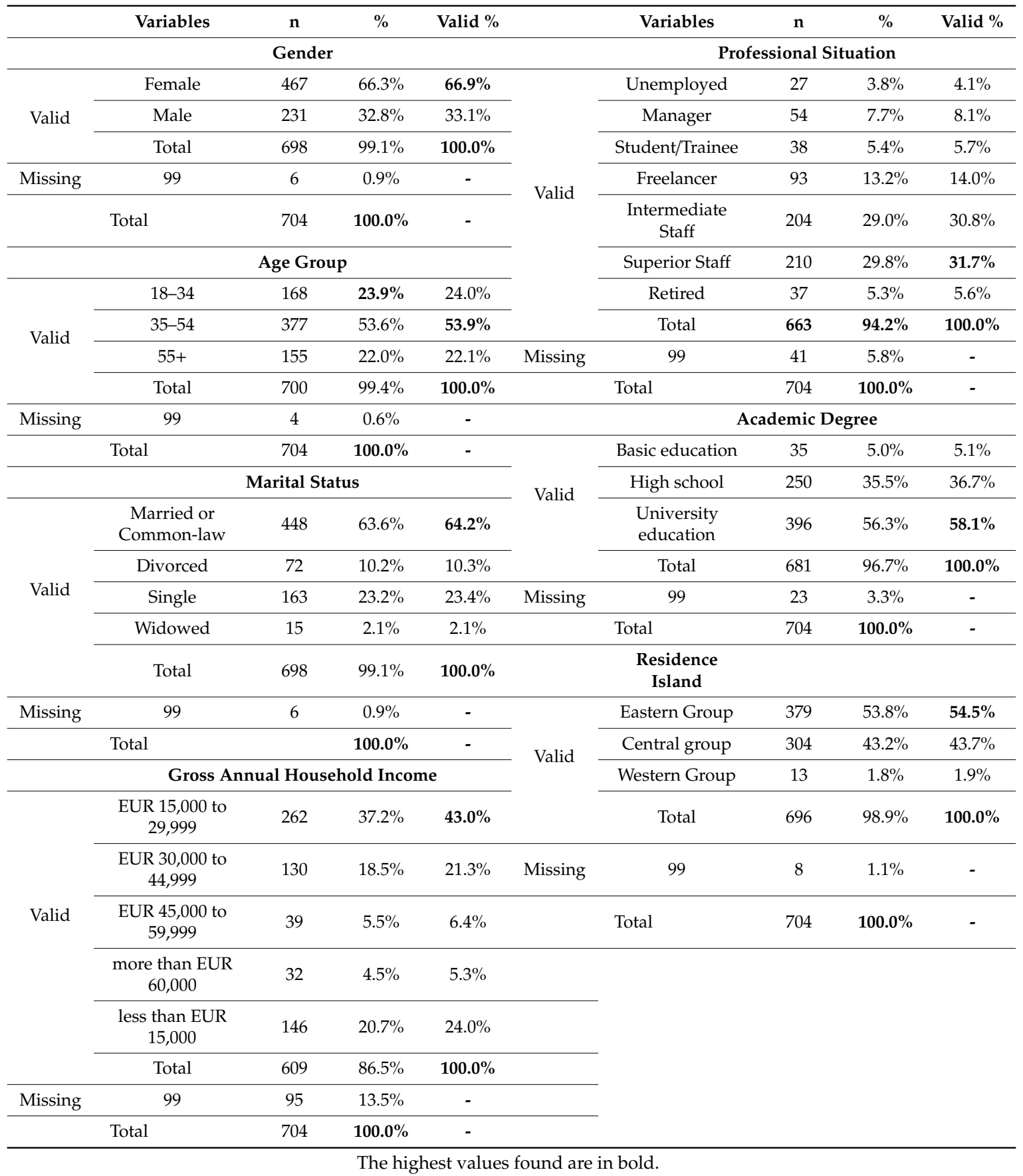

Subsequently, three closed-ended questions regarding the COVID-19 impacts on planned or ongoing trips were formulated (see Table 2).

Regarding the first question, a large percentage of respondents (48.9\%) replied that the COVID-19 crisis affected the course of their trips. Additionally, in question two, when the participants were asked if they needed to cancel or reschedule any trips planned, the most significant portion of the respondents said yes $(60.9 \%)$. With question three, it was possible to verify that the majority of the participants (74.1\%) changed their vacation plan for 2020 due to the COVID-19 crisis.

Furthermore, concerning the multiple answers question "what has changed in your vacation plan?", from the 603 respondents who selected at least one of the four possible response options 
(Table 3), about $40.5 \%$ canceled the vacation travel, $37.8 \%$ gave up traveling abroad, $20.9 \%$ changed their vacation destination, and $35.8 \%$ changed their vacation period.

Table 2. Closed-ended questions.

\begin{tabular}{|c|c|c|c|c|c|}
\hline Questions & & Categories & $\mathbf{n}$ & $\%$ & Valid \% \\
\hline \multirow{4}{*}{$\begin{array}{l}\text { (i) Did the COVID- } 19 \text { crisis } \\
\text { affect the plan for any trip you } \\
\text { were taking? }\end{array}$} & \multirow[b]{2}{*}{ Valid } & $\mathrm{No}$ & 358 & $50.9 \%$ & $51.1 \%$ \\
\hline & & Yes & 342 & $48.6 \%$ & $48.9 \%$ \\
\hline & \multirow{3}{*}{ Missing } & Total & 700 & $99.4 \%$ & $100.0 \%$ \\
\hline & & 99 & 4 & $0.6 \%$ & - \\
\hline \multirow{5}{*}{$\begin{array}{l}\text { (ii) Because of COVID-19, did } \\
\text { you cancel or reschedule any } \\
\text { trips you had planned? }\end{array}$} & & Total & 704 & $100.0 \%$ & - \\
\hline & \multirow{3}{*}{ Valid } & No & 274 & $38.9 \%$ & $39.1 \%$ \\
\hline & & Yes & 427 & $60.7 \%$ & $60.9 \%$ \\
\hline & & Total & 701 & $99.6 \%$ & $100.0 \%$ \\
\hline & Missing & 99 & 3 & $0.4 \%$ & - \\
\hline \multirow{6}{*}{$\begin{array}{l}\text { (iii) Because of COVID-19, } \\
\text { have you changed your } \\
\text { vacation plan for } 2020 ?\end{array}$} & \multicolumn{2}{|c|}{ Total } & 704 & $100.0 \%$ & - \\
\hline & \multirow{3}{*}{ Valid } & No & 181 & $25.7 \%$ & $25.9 \%$ \\
\hline & & Yes & 518 & $73.6 \%$ & $74.1 \%$ \\
\hline & & Total & 699 & $99.3 \%$ & $100.0 \%$ \\
\hline & & 99 & 5 & $0.7 \%$ & - \\
\hline & \multicolumn{2}{|c|}{$\begin{array}{l}\text { Missing } \\
\text { Total }\end{array}$} & 704 & $100.0 \%$ & - \\
\hline
\end{tabular}

The highest values found are in bold.

Table 3. Multiple response analysis.

\begin{tabular}{|c|c|c|c|c|}
\hline \multicolumn{5}{|c|}{ Linked Options } \\
\hline & & \multicolumn{2}{|c|}{ Responses } & \multirow{2}{*}{$\%$ of Cases } \\
\hline & & $\mathbf{n}$ & $\%$ & \\
\hline \multirow{4}{*}{ Linked_options4 ${ }^{\text {a }}$} & OP1-I canceled the vacation trip & 244 & $30.0 \%$ & $40.5 \%$ \\
\hline & OP2-I gave up traveling abroad & 228 & $28.0 \%$ & $37.8 \%$ \\
\hline & OP3 - I changed my vacation destination & 126 & $15.5 \%$ & $20.9 \%$ \\
\hline & OP4-I changed my vacation dates & 216 & $26.5 \%$ & $35.8 \%$ \\
\hline & Total & 814 & $100.0 \%$ & $135.0 \%$ \\
\hline
\end{tabular}

The highest values found are in bold. ${ }^{a}$ Dichotomy group tabulated at value 1.

A single response question was made. In that question, the following was asked: What are your vacation plans for 2020? (Table 4). From the answers, it was possible to highlight the most selected response (57.5\%): I will protect myself and spend the holidays at my usual residence; $14.3 \%$ said they would choose a less typical destination, $11.5 \%$ said they would not take a vacation this year (2020), and (16.7\%) selected the option "Other".

Three single-response questions focused on vacation intentions in 2020 (if the participants are travelling on vacation in 2020, which are the locations for such vacations, and if the participants have already booked a 2020 vacation), as is shown in Table 5 . With the first two questions results, it was evident that the significant part of the participants (57.5\%) will not be going to travel to spend vacations in 2020. Additionally, (84.2\%) will have holidays on the Azores Archipelago, therefore, they stay in the region. Besides, according to question 3 , the majority of the respondents $(61.6 \%)$ stated that they would not make a reservation for the 2020 vacation. 
Table 4. Single response question: what are your vacation plans for 2020 ?

\begin{tabular}{|c|c|c|c|c|}
\hline & Answers & $\mathbf{n}$ & $\%$ & Valid \% \\
\hline & $\begin{array}{l}\text { 1. I will protect myself and spend the holidays } \\
\text { at my usual residence. }\end{array}$ & 390 & $55.4 \%$ & $57.5 \%$ \\
\hline \multirow[t]{4}{*}{ Valid } & 2. I would choose a less typical destination. & 97 & $13.8 \%$ & $14.3 \%$ \\
\hline & 3. I would not take a vacation this year 2020 . & 78 & $11.1 \%$ & $11.5 \%$ \\
\hline & 4. Other. & 113 & $16.1 \%$ & $16.7 \%$ \\
\hline & Total & 678 & $96.3 \%$ & $100.0 \%$ \\
\hline Missing & 99 & 26 & $3.7 \%$ & - \\
\hline \multicolumn{2}{|r|}{ Total } & 704 & $100.0 \%$ & - \\
\hline
\end{tabular}

The highest values found are in bold.

Table 5. Single-response questions.

\begin{tabular}{|c|c|c|c|c|c|}
\hline \multicolumn{2}{|c|}{$\begin{array}{l}\text { Question 1-Are You Going to Travel in the } \\
2020 \text { Vacation? }\end{array}$} & \multirow{2}{*}{$\begin{array}{c}\mathbf{n} \\
402\end{array}$} & \multirow{2}{*}{$\begin{array}{c}\text { \% } \\
57.1 \%\end{array}$} & \multirow{2}{*}{$\begin{array}{c}\text { Valid \% } \\
57.5 \%\end{array}$} & \multirow{2}{*}{$\begin{array}{c}\text { Cumulative \% } \\
57.5 \%\end{array}$} \\
\hline & No & & & & \\
\hline \multirow[t]{3}{*}{ Valid } & Yes & 159 & $22.6 \%$ & $22.7 \%$ & $80.3 \%$ \\
\hline & Maybe & 138 & $19.6 \%$ & $19.7 \%$ & $100.0 \%$ \\
\hline & Total & 699 & $99.3 \%$ & $100.0 \%$ & - \\
\hline \multirow[t]{2}{*}{ Missing } & 99 & 5 & $0.7 \%$ & - & - \\
\hline & Total & 704 & 100.0 & - & - \\
\hline \multicolumn{2}{|c|}{$\begin{array}{c}\text { Question 2-Where will the Holidays } \\
\text { be Taken? }\end{array}$} & $\mathbf{n}$ & $\%$ & Valid \% & Cumulative $\%$ \\
\hline \multirow{5}{*}{ Valid } & Azores & 558 & $79.3 \%$ & $84.2 \%$ & $84.2 \%$ \\
\hline & In the Foreign & 29 & $4.1 \%$ & $4.4 \%$ & $88.5 \%$ \\
\hline & Madeira & 7 & $1.0 \%$ & $1.1 \%$ & $89.6 \%$ \\
\hline & Portugal Mainland & 69 & $9.8 \%$ & $10.4 \%$ & 100.0 \\
\hline & Total & 663 & $94.2 \%$ & $100.0 \%$ & - \\
\hline \multirow[t]{2}{*}{ Missing } & 99 & 41 & $5.8 \%$ & - & - \\
\hline & Total & 704 & 100.0 & - & - \\
\hline \multicolumn{2}{|c|}{$\begin{array}{l}\text { Question 3-Have You Already Booked for } \\
\text { the } 2020 \text { Vacation? }\end{array}$} & $\mathbf{n}$ & $\%$ & Valid \% & Cumulative $\%$ \\
\hline \multirow{4}{*}{ Valid } & I will still make & 173 & $24.6 \%$ & $25.3 \%$ & $25.3 \%$ \\
\hline & I will not make reservation & 421 & $59.8 \%$ & $61.6 \%$ & $87.0 \%$ \\
\hline & Partial & 36 & $5.1 \%$ & $5.3 \%$ & $92.2 \%$ \\
\hline & Yes & 53 & $7.5 \%$ & $7.8 \%$ & $100.0 \%$ \\
\hline & Total & 683 & $97.0 \%$ & 100.0 & - \\
\hline \multirow[t]{2}{*}{ Missing } & 99 & 21 & $3.0 \%$ & - & - \\
\hline & Total & 704 & $100.0 \%$ & - & - \\
\hline
\end{tabular}

The highest values found are in bold.

The survey presents a section regarding the participants' agreement levels (Table 6). So, by a Likert-scale assessment method, the respondents were asked to declare their agreement with six 
sentences-where 1 is totally disagree and 5 totally agree. Concerning the first sentence (i): I will trust and choose a tourist accommodation with a sanitary and hygiene seal (like "Covid-19 Free and Safe") assigned by Turismo de Portugal and health authorities; the most selected agreement level was $4(38.3 \%)$, followed by agreement level $5(25.4 \%)$, and the third agreement level selected was $3(25.0 \%)$. Thus, revealing a clear trend of agreement with this sentence (sentence i). Similar outcomes have been verified in sentences ii, iii, and iv. Nevertheless, in the sentence (ii): I will travel more securely if the use of masks and visors is widespread in the destination, the most selected agreement level was $4(33.3 \%)$, the third most agreement level chosen was $2(20.3 \%)$. In addition, with a positive tendency, we have the sentence (v): COVID-19 came to show that it is best to take a vacation in the countryside (highest in agreement level 3 with 30.8\%); yet, for this sentence, a remarkable 21.0\% selected agreement level 2, but still the second most selected agreement was level 4 with $25.3 \%$. The only sentence that shows a clear disagreement tendency is number vi-In the future, I will avoid air travel — where the agreement level most selected is number $2(33.3 \%)$, followed closely by agreement level $1(33.0 \%)$, and then by the third most selected agreement level 3 (21.0\%).

Table 6. Likert-scale questions.

\begin{tabular}{l}
\multicolumn{1}{c}{ Sentences } \\
\cline { 2 - 5 }
\end{tabular}

The highest values found are in bold. ${ }^{*} 1$-Totally disagree; 5 - totally agree.

The Ascendant Hierarchical Cluster Analysis (AHCA) of the six items of Table 6 was based on the affinity coefficient [33] (similarity coefficient) in order to obtain a typology of this set of items. This coefficient measures the extent of a monotonic relation between square root profiles of probabilities, and is also suitable for ordinal variables, as is the case of this set of items. This measure of comparison between elements was combined with two classical aggregation criteria, Single Linkage (SL) and Complete Linkage (CL) [34], and three probabilistic aggregation criteria, AVL (Aggregation Validity Link), AV1, and AVB (Aggregation Validity B-Link) [35,36], within the scope of the VL Methodology (V for validity, L for linkage) (Figures 3 and 4). According to Nicolau and Bacelar-Nicolau ([35] p. 89):

"Applications on either simulated or real data set have shown this probabilistic approach performs better than the traditional one (using empirical clustering methods) in many situations".

According to the global statistics of levels, STAT $[35,37]$, the best partition is a partition into three clusters obtained at level 3 by all aggregation criteria (STAT $=2.8723)$ : Cluster $1:\{i$, ii $\}$; Cluster 2: \{iii, iv, v\}; and Cluster 3: \{vi\}. 


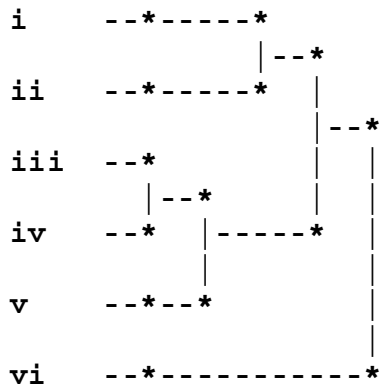

Figure 3. Dendrogram obtained with single linkage (SL), AV1 and AVB methods.

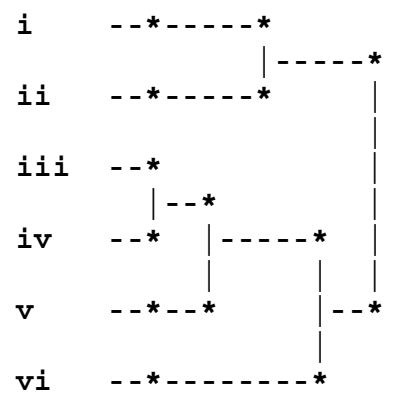

Figure 4. Dendrogram obtained with complete linkage (CL) and AVL methods.

The dendrograms of Figures 3 and 4 highlight the high similarities between respondents' perceptions regarding items iii ("COVID-19 came to show that we should avoid popular tourist destinations") and iv ("COVID-19 came to show that we should avoid taking vacations during periods of the year with a lot of demand"). The selected partition reinforces the belief that the item that departs most from the rest, in the perception of the respondents, is item vi ("In the future, I will avoid air travel"), that as we saw above is the only sentence that is subject to a clear disagreement propensity. This attitude shows some optimism on the part of participants concerning air travel.

\section{Discussions and Conclusions}

A large percentage of the respondents (48.9\%) responded that the crisis caused by COVID-19 affected the course of any trip they were taking. The majority $(60.9 \%)$ said that they canceled or had to reschedule some trip they had scheduled, and $74.1 \%$ of respondents changed their holiday plan to 2020 because of the pandemic situation.

Concerning the changes made by respondents to their holiday plan due to the pandemic by COVID-19, it should be noted that $40.5 \%$ canceled the holiday trip, $37.8 \%$ gave up traveling abroad, $20.9 \%$ changed the holiday destination, and $35.8 \%$ changed the holiday period.

In the holiday plan for the year 2020, it is noteworthy that the majority (57.5\%) replied that they preferred to protect themselves in their residence, and $61.6 \%$ said that they would not make a holiday reservation in 2020.

However, $57.5 \%$ of respondents said they would not travel for holidays, preferring (84.2\%) to enjoy holidays in the Azores. Considering the fear of traveling abroad, the regional government has created an incentive to take a holiday in the Azores intended exclusively for residents. The incentive covers air transport services, accommodation, food, tourist activities, car rental, and booking expenses. It is set at $50 \%$ of the amount paid, up to the maximum limit of EUR 150.00 per person. The incentive has an increase of EUR 25.00, in case the beneficiary resorts to car rental.

More than half of respondents consider that the "Clean and Safe" quality is essential in choosing accommodation and restaurants $(75.8 \%)$ and in choosing the destination to visit $(50.5 \%)$, so all efforts 
that can be made by the competent authorities and entrepreneurs to ensure the hygiene seal is beneficial to the destination.

A significant percentage of the respondents (42.3\%) said they are willing to pay more for a safe holiday. It should also be noted that $41.4 \%$ consider this possibility. Only $16.2 \%$ of respondents answered that they do not intend to spend more on this guarantee.

However, significant differences were found between at least two age groups (between the youngest and the oldest) regarding the attitudes analyzed about the problems described above. In part, these outcomes could be explained by generation-gap disparities. More often, it is noticed that younger tourists are interested in more slow tourism-mostly because of the connection between this topology of tourism and sustainability. Perhaps the media and marketing around this topic could be one of the decisive factors. Another relevant factor of differentiation is due to the level of education, given that the younger generations have a higher education level than the older generations. In 1956, four years of primary education became compulsory only for males and only later for females, in 1960 . Compulsory schooling underwent an extension until the 12th grade already in 2009. The Portuguese State defends now that 12 years of schooling are relevant to the social, economic and cultural progress of the population and the country. Finally, the degree of risk aversion is also a differentiating factor between generations, with older people being more risk averse than younger ones.

Differences were also found between at least two of the groups of islands defined by the geographical location of the islands. These differences are about the levels of agreement with the use of masks and visors to make holidays and trips safer. The significant differences are those related to the comparisons between the Eastern Group and the Central Group and between the Eastern Group and the Western Group. It should be noted that it is the Eastern Group's individuals who mostly tend to agree with this procedure. The Eastern group is the group where São Miguel's Island is located. This Island is the most affected in the Azores Archipelago island by COVID-19, with the greater number of cases reported. Therefore, São Miguel is where the need to wear a mask has been felt more strongly. It should be highlighted that Ponta Delgada is considered the main gateway for tourists in the region.

The pandemic caused by COVID-19 has substantially changed the paradigm of residents' attitudes in choosing the time and form of vacation. Although it does not solve the very significant crisis that has plagued the region (a brutal drop in the tourism sector), we can mention that the adverse effects were more significant due to the choice on the part of residents to holiday in the Azores, enjoying local experiences, preferably on islands other than that of their residence.

Domestic tourism has always been the salvation of tourist destinations that suffer external shocks and negative snapshots in the external demand of international tourists. However, the need to catch a plane for domestic tourism from mainland Portugal to the islands has become a very harmful condition in the current pandemic context. Additionally, there is a need to test for the virus.

It remains a necessity to promote a safe and natural destination to attract more tourists in the current context and promote intra and inter-island tourism. However, it is constrained from an economic point of view.

Throughout this research, it becomes evident how the COVID-19 pandemic crisis affected the Azores Islands residents' tourism. Thus, the authors believe that the data obtained for this study could be pivotal to properly design and implement regional strategies to face the sanitary crisis of COVID-19. In fact, the results show the intentions of the tourism expectations and intentions of the Azores Archipelago residents, therefore, these results should be understood to increase the tourism safety measures in tourism activities in order not only to stimulate this activity but also to relaunch the regional economy and development.

Even if the negative impacts of this crisis are inevitable, at the same time, it opens a window of opportunity to invest new models of tourism activities in the Archipelago-i.e., agritourism; adventure tourism; sport tourism; ecotourism; gastronomy tourism; cultural tourism; or nature-based tourism, are just some examples. As previous authors affirm [28,30,31,38], there is considerable potential for the growth and development of rural and slow tourism in the Azores Archipelago. Additionally, this 
typology of tourism is seen by many authors (see: [39-45] Labrianidis, and Thanassis, 2003; Reeder and Brown, 2005; Buckley, 2007; Morais et al., 2018; 2019; Santos, Castanho, and Lousada, 2019; or Ulucak, Yücel, and Koçak, 2019) as a vehicle to achieve regional sustainable development.

Additionally, tourism in the Azores is a strategic sector for the regional economy and growth. Moreover, adventure and nature tourism are the frontline merchandise of this model in the region, which increases the relevance of the obtained data for the territorial planning and management of the Archipelago. Based on this premise, new tourism sector dynamics and more tourism activities and companies were created in recent years, increasing the diversity of offer to the tourists, and it could be amplified by the actual situation - considering the intentions of the residents to take vacations within the region. Accordingly, it seems that the Archipelago already has several practical and administrative resolutions that could promote the investment in this typology of tourism and, in the medium-term, reshape territorial public policies in a more sustainable way.

Thereby, the main actors and regional decision-makers should use this opportunity to envision a more sustainable future for the Azores.

\section{Study Limitations and Additional Research Lines}

Even if this investigation expands our understanding of how the COVID-19 pandemic crisis affected the Azores residents' tourism expectations, several possibilities for future research persist. For example, this topic opens a window of opportunity to further study and assess the Azores' tourism potential during and after the COVID-19 crisis, or to compare the regional tourism industry and regional residents' intentions towards their holidays during and after this pandemic crisis.

Moreover, the current research was conducted for the Azores region as a whole. Nevertheless, if individual studies were carried out in each of the nine islands of the Archipelago, our knowledge regarding this issue could increase.

Besides, it is a well-known fact that territorial strategies (including the regional public policies) are often changing in the regions [46-49], making evident the need for close monitoring processes and new research over the dynamics and tendencies of the factors that could influence this territorial changes. In this regard, particular attention should be focused on public perceptions and in the evolution of the COVID-19 sanitary crisis in all panoramas.

Although this article contributed an investigation relating to the vital aspects in facing this crisis and growth towards sustainable development in the COVID-19 period, in the particular case of Azores Archipelago, if more surveys and variables were managed and chosen, it would afford us more robust, and broader conclusions.

The use of a non-probability sampling method does not guarantee the generalization of results for the population, which is the main limitation of the present investigation. Thus, we have chosen to present only the most robust results of our study. Thereby, we believe that the present work constitutes a good starting point for further research on the addressed topic.

Furthermore, the authors believe this typology of investigation should be conducted and extrapolated to other case studies and regions.

Author Contributions: All the authors contributed equally in the development of the present paper. All of the phases of the paper development proper have been discussed and worked on by the authors. All authors have read and agreed to the published version of the manuscript.

Funding: This paper is financed by Portuguese national funds through FCT—Fundação para a Ciência e a Tecnologia. I.P. project number UIDB/ECO/00685/2020 and also by the project GREAT—Genuine Rural Experiences in the Azores Tourism with the code: ACORES-01-0145-FEDER-000089.

Conflicts of Interest: The authors declare no conflict of interest. 


\section{References}

1. Mora Aliseda, J. El Coronavirus Obliga a una Respuesta Sin. Fronteras Special Issue of: Reflexiones Aobre el coronavirus y sus Impactos in Revista Científica Monfragüe Resiliente-Scientific Journal. 2020, pp. 6-8. Available online: https://www.eweb.unex.es/eweb/monfragueresilente/Monografico\%20Covid\%2019.pdf (accessed on 14 July 2020).

2. Gössling, S.; Scott, D.; Hall, C.M. Pandemics, tourism and global change: A rapid assessment of COVID-19. J. Sustain. Tour. 2020,1-20. [CrossRef]

3. Tatem, A.; Rogers, D.; Hay, S.I. Global Transport Networks and Infectious Disease Spread. Adv. Parasitol. 2006, 62, 293-343. [CrossRef]

4. Wilson, M. Global travel and emerging infections. In Infectious Disease Movement in a Borderless World: Microbial Threats Forum. Institute of Medicine. Workshop Summary; The National Academies Press: Washington, DC, USA, 2010; pp. 90-104.

5. Browne, A.; Ahmad, S.S.-O.; Beck, C.R.; Nguyen-Van-Tam, J.S. The roles of transportation and transportation hubs in the propagation of influenza and coronaviruses: A systematic review. J. Travel Med. 2016, 23. [CrossRef]

6. Abud, D. Essay: Covid-19. Efects in the International Trade of Rep. Dominican and Other Latin American Countries. Special Issue of: Reflexiones Sobre el Coronavirus y sus Impactos in Revista Científica Monfragüe Resiliente-Scientific Journal. 2020, pp. 26-29. Available online: https://www.eweb.unex. es/eweb/monfragueresilente/Monografico\%20Covid\%2019.pdf (accessed on 14 July 2020).

7. CEPAL-Comisión Económica para América Latina y el Caribe. América Latina y el Caribe ante la Pandemia del COVID-19. 2020. Available online: https://repositorio.cepal.org/bitstream/handle/11362/45337/4/S2000264_es. pdf (accessed on 14 July 2020).

8. Espinoza, D. La Propuesta de Trabajo de Costa Rica para Atender en la Crisis Pandémica por el SARS-COV-2 y la Participación de las Universidades Estatales. Special Issue of: Reflexiones sobre el coronavirus y sus impactos in Revista Científica Monfragüe Resiliente-Scientific Journal. 2020, pp. 66-80. Available online: https://www.eweb.unex.es/eweb/monfragueresilente/Monografico\%20Covid\%2019.pdf (accessed on 14 July 2020).

9. Castanho, R.A. A pandemic crisis shocking us all: The covid-19. Special Issue of: Reflexiones sobre el coronavirus y sus impactos in Revista Científica Monfragüe Resiliente-Scientific Journal. 2020, pp. 233-238. Available online: https://www.eweb.unex.es/eweb/monfragueresilente/Monografico\%20Covid\%2019.pdf (accessed on 14 July 2020).

10. Maliszewska, M.; Mattoo, A.; van der Mensbrugghe, D. The Potential Impact of COVID-19 on GDP and Trade. A Preliminary Assessment. Policy Research Working Paper 9211. East Asia and the Pacific Region Office of the Chief Economis and Macroeconomics. Trade and Investment Global Practice April 2020. Available online: https://openknowledge.worldbank.org/handle/10986/33605?show=full (accessed on 14 July 2020).

11. Mckibbin, W.; Roshen, F. The economic impact of COVID-19. In Economics in the Time of COVID-19; Centre for Economic Policy Research: London, UK, 2020.

12. Ramírez-Silva, J.P. Una Óptica Sustentable del Turismo Post Covid-19. Available online: http://documents1.worldbank.org/curated/en/295991586526445673/pdf/The-Potential-Impact-of-COVID19-on-GDP-and-Trade-A-Preliminary-Assessment.pdf (accessed on 12 July 2020).

13. The Impacts of COVID-19 on the Forest Sector: How to Respond? FAO: Rome, Italy, 2020.

14. OECD. The impact of the coronavirus (COVID-19) crisis on development finance. Available online: https://read.oecd-ilibrary.org/view/?ref=134_134569-xn1go1i113\&title=The-impact-of-the-coronavirus(COVID-19)-crisis-on-development-finance (accessed on 21 July 2020).

15. Ozili, P.K.; Arun, T. Spillover of COVID-19: Impact on the Global Economy. SSRN Electron. J. $2020,10$. [CrossRef]

16. Burkle, F.M. Globalization and disasters: Issues of public health State capacity and political action. J. Int. Aff. 2006, 59, 231-265.

17. Gössling, S. Global environmental consequences of tourism. Glob. Environ. Chang. 2002, 12, $283-302$. [CrossRef] 
18. Hall, C.M. Tourism, biodiversity and global environmental change. In Tourism and Global Environmental Change: Ecological. Economic. Social and Political Interrelationships; Gossling, S., Hall, C.M., Eds.; Routledge: Abingdon-on-Thames, UK, 2006; pp. 142-156.

19. Page, S.; Yeoman, I. How Visit Scotland prepared for a flu pandemic. J. Bus. Contin. Emer. Plan. 2007, 1, 167-182.

20. Fauci, A.S.; Morens, D.M. The Perpetual Challenge of Infectious Diseases. N. Engl. J. Med. 2012, 366, 454-461. [CrossRef] [PubMed]

21. Abukhalifeh, A.; Faller, E.; Ahmad, A.; Tadros, S. Current Issue in Tourism: Diseases Transformation as a Potential Risks for Travellers. Glob. Stoch. Anal. 2018, 5, 341-350.

22. Scott, D.; Gössling, S. What could the next 40 years hold for global tourism? Tour. Recreat. Res. 2015, 40, 269-285. [CrossRef]

23. Qureshi, A.I. Economic and Political Impact of Ebola Virus Disease; Elsevier BV: Amsterdam, The Netherlands, 2016; pp. 177-191.

24. Qiu, W.; Chu, C.; Mao, A.; Wu, J. The Impacts on Health, Society, and Economy of SARS and H7N9 Outbreaks in China: A Case Comparison Study. J. Environ. Public Health 2018, 2018, 1-7. [CrossRef] [PubMed]

25. Rossello, J.; Santana-Gallego, M.; Awan, W. Infectious disease risk and international tourism demand. Health Policy Plan. 2017, 32. [CrossRef] [PubMed]

26. Bloom, D.E.; Cadarette, D. Infectious Disease Threats in the Twenty-First Century: Strengthening the Global Response. Front. Immunol. 2019, 10, 549. [CrossRef]

27. Castanho, R.A.; Couto, G.; Pimentel, P. Principles of Sustainable Tourism and Cultural Management in Rural and Ultra-peripheral Territories: Extracting Guidelines for Application in the Azores Archipelago. Cult. Manag. Sci. Educ. 2020, 4, 9-24. [CrossRef]

28. Ponte, J.; Couto, G.; Pimentel, P.; Oliveira, A.; De Maneio, P.D.F. Tourism activities and companies in a sustainable adventure tourism destination: The Azores. Tour. Manag. Stud. 2018, 14, 25-38. [CrossRef]

29. Ferreira, H.M. Diversity Patterns of Honey bee (Apis mellifera L.) Populations from the Archipelago of the Azores: Insights from mtDNA and Wing Geometric Morphometrics. Master's Thesis, University of Porto, Porto, Portugal, 30 November 2017.

30. Vieira, J.C.; Couto, G.; Pimentel, P.M.; Menezes, A.; Moniz, A.I.; Sousa, F. The Satisfaction of the Nordic Tourist with the Azores as a Destination. Scand. J. Hosp. Tour. 2013, 13, 58-72. [CrossRef]

31. Silva, F.; Almeida, M.C. Sustentabilidade do turismo na natureza nos Açores-O caso do canyoning. In Turismo e Desporto na Natureza; Em Almeida, M.C., Ed.; Associação de Desportos de Aventura Desnível: Estoril, Portugal, 2013; pp. 5-19.

32. Couto, G.; Pimentel, P.M.; Ponte, J. Tourism Development Potential in an Insular Territory: The Case of Ribeira Grande in the Azores. J. Tour. Res. Hosp. 2017, 6. [CrossRef]

33. Nicolau, H.B. On the Distribution Equivalence in Cluster Analysis. In Pattern Recognition Theory and Applications; Springer Science and Business Media LLC: Berlin/Heidelberg, Germany, 1987; pp. 73-79.

34. Anderberg, M.R. Cluster Analysis for Applications; Elsevier BV Academic Press: New York, NY, USA, 1973.

35. Nicolau, F.C.; Bacelar-Nicolau, H. Some Trends in the Classification of Variables. Stud. Classif. Data Anal. Knowl. Organ. 1998, 89-98. [CrossRef]

36. Lerman, I.C. Classification et Analyse Ordinale des Données; Dunod: Paris, France, 1981.

37. Lerman, I.-C. Foundations and Methods in Combinatorial and Statistical Data Analysis and Clustering. In Secure Information Management Using Linguistic Threshold Approach; Springer Science and Business Media LLC: Berlin/Heidelberg, Germany, 2016.

38. Castanho, R.A.; Couto, G.; Pimentel, P.; Carvalho, C.B.; Sousa, Á. Territorial Management and Governance, Regional Public Policies and their Relationship with Tourism. A Case Study of the Azores Autonomous Region. Sustainability 2020, 12, 6059. [CrossRef]

39. Buckley, R.C. Adventure tourism products: Price, duration, size, skill, remoteness. Tour. Manag. 2007, 28, 1428-1433. [CrossRef]

40. Labrianidis, L.; Thanassis, K. A Suggested Typology of Rural Areas in Europe. Available online: https: //www.Cordis.europa.eu (accessed on 2 August 2020).

41. Morais, J.; Castanho, R.A.; Gomes, C.J.P.; Santos, P. Characteristics of Iona National Park's visitors: Planning for ecotourism and sustainable development in Angola. Cogent Soc. Sci. 2018, 4, 1-15. [CrossRef] 
42. Morais, J.; Castanho, R.A.; Loures, L.; Gomes, C.J.P.; Santos, P. Villagers' Perceptions of Tourism Activities in Iona National Park: Locality as a Key Factor in Planning for Sustainability. Sustainability 2019, 11, 4448. [CrossRef]

43. Reeder, R.J.; Brown, D.M. Recreation, Tourism, and Rural Well-Being; BiblioGov: London, UK, 2005.

44. Santos, R.; Castanho, R.A.; Lousada, S. Return Migration and Tourism Sustainability in Portugal: Extracting Opportunities for Sustainable Common Planning in Southern Europe. Sustainability 2019, 11, 6468. [CrossRef]

45. Ulucak, R.; Yücel, A.G.; Koçak, E. The Process of Sustainability. Environ. Kuznets Curve 2019, 6, 37-53.

46. Gómez, J.M.N.; Lousada, S.; Velarde, J.G.; Castanho, R.A.; Loures, L. Land-Use Changes in the Canary Archipelago Using the CORINE Data: A Retrospective Analysis. Land 2020, 9, 232. [CrossRef]

47. Rodas, J.M.C.; Castanho, R.A.; Fernández, J.C.; Gómez, J.M.N. Sustainable valuation of land for development. Adding value with urban planning progress. A Spanish case study. Land Use Policy 2020, 92, 104456. [CrossRef]

48. Castanho, R.A.; Lousada, S.; Gómez, J.M.N.; Escórcio, P.; Cabezas, J.; Fernández-Pozo, L.; Loures, L. Dynamics of the Land Use Changes and the Associated Barriers and Opportunities for Sustainable Development on Peripheral and Insular Territories: The Madeira Island (Portugal). In Land Use-Assessing the Past, Envisioning the Future; IntechOpen: London, UK, 2019.

49. Loures, L.; Castanho., R.A.; Vulevic, A.; Naranjo Gómez, J.; Cabezas., J.; Fernández-Pozo, L. The Multi-variated Effect of City Cooperation in Land Use Planning and Decision-making Processes-A European Analysis. In Urban Agglomerations; InTech.: London, UK, 2018; pp. 87-106.

(C) 2020 by the authors. Licensee MDPI, Basel, Switzerland. This article is an open access article distributed under the terms and conditions of the Creative Commons Attribution (CC BY) license (http://creativecommons.org/licenses/by/4.0/). 